\title{
Differential Perception of Roles and Conflict in the Management of Financial Resources: The Case of Stakeholders in Public Secondary Grammar Schools in the South West Region of Cameroon
}

\author{
Fonge Julius Fongouck* \\ Ph.D. Fellow, Department of Educational Foundations and Administration, Faculty of Education, University of \\ Buea, P. O. 63. Cameroon \\ *Corresponding Author: Fonge Julius Fongouck, Ph.D. Fellow, Department of Educational \\ Foundations and Administration, Faculty of Education, University of Buea, P. O. 63. Cameroon
}

\begin{abstract}
Since the holding of the National Forum on Education in Cameroon in1995, the government has through a number of statuses, empowered citizens and parents, through School Councils(School Management Boards (SMB), the Parent Teacher Association (PTA), to partner with school Principals as collaborative stakeholders, to manage school resources with the intention of improving school outcomes. These stakeholders have been conflicting with one another over who should perform which role. This study therefore seeks to investigate the conflicts emanating from the execution of roles with regards to financial resources. Most importantly, it seeks to find out if such conflicts observed in Public Secondary Grammar Schools (PSGS) are resulting from the differences in perception of financial roles by these stakeholders. The study employed a multi-stage sampling technique which included non-probability (purposive or judgmental sampling) to select the South West Region and a probability technique to come up with respondents (76 principals, 75 SMB chairpersons, and 75 PTA presidents). Data were collected using questionnaire, interview guide and documentary evidence. Collected data were subjected to descriptive and inferential statistics. For descriptive statistics, frequencies and percentages were used, while bar charts and pie charts were used to present data. For inferential statistics, the Pearson Correlation Coefficient Product Moment were used to verify the hypotheses. Findings indicated that the correlation between differences in perception of financial roles by stakeholders and conflicts in the management of financial resources was significant with an rxy computed value of 0.79. Based on the results, it was recommended that government codifies all texts on school governance, particularly with regards to management roles for stakeholders. It also recommended stakeholders be trained on how to manage various finances and that they should be adequately educated on their roles through seminars.
\end{abstract}

Keywords: Decentralization, Differential Perception, Stakeholders, Roles, Conflicts and Resources

\section{INTRODUCTION}

\subsection{Context and Justification of the Study}

The study is situated within the context of Educational Decentralization in Cameroon, in which two school governance structures (School Councils), here after referred to as the School Management Board (SMB), and the Parent Teacher Association (PTA) were created and/or recognized as managing structures in PSGS and attributed roles in the management of resources, particularly in the domain of policy formation and implementation; and the management of financial, material and human resources. This study is focused specifically on the roles of these stakeholders in the management of financial resources in PSGS in the South West Region of Cameroon.

Concerning financial resources, prior to 1982, all PSGS in Cameroon depended on the central ministry in Yaoundé for the supply of money to meet up with the most basic of their needs. This was as a result of the fact that the educational system was essentially over centralized (MINESEC, 1994/1995; Tambo, 2003; Mbua, 2002, 2003, Tamukong 2004; and Fonkeng, 2006). In fact, every aspect of secondary education in Cameroon (infrastructural provisions, teachers, subventions of all kinds and other educational deliveries, waited for government intervention or sponsorship and this with attendant negative consequences. 
This situation in which school were completely run from Yaounde, prevailed for two decades and in fact, with catastrophic results. Ndongko (1989), states that for two decades since independence, schools in Cameroon have been perceived to be performing at almost unacceptable levels, this according to her was evidenced in the classroom examination and in the results at end-of-course and public examination. Furthermore, World Bank (1992)report in Ayuk (2012) and Ndongko (1989)described the educational system of Cameroon as being in deep crisis and badly in need of reforms is best encapsulated in the 1994 Forum on Education documents (MINESEC, 1994).These documents outlined the problems bedevilling the Basic and Secondary Educational sectors in Cameroon, such as over-centralization, structural deficiencies (acute shortage of classroom buildings, dilapidating classroom, inexistent and insufficient offices, lack of libraries, gymnasiums, playgrounds, water points and toilets), overcrowded classrooms, shortages of teachers, unstable teaching staff, often victims of untimely postings and transfers. This deplorable situation was further confirmed/reported by Adeogun (2001), Ajayi 2001, Akumah and Gana (2005) and Bessong (2013).

In order to bring about the much needed changes in our educational system, the new political regime that came to power in 1982 had to acknowledge certain realities; that the educational system was centralized, poor and needed an overhaul; that this system with much ministerial control and with too much dependence on the school principal, was archaic and was not practical, particularly it was not organized to meet up with the challenges of the $21^{\text {st }}$ century; that the Cameroon government could not do it alone and that examples from other countries (developing and developed) have acknowledged that schools where community or parents' involvement in the management of resources through Board of Governors (BOGs) and Parent Teachers Association exist (Kemba2001, in Onderi and Makori, 2012), have contributed enormously in improving standards, therefore, that reforms in which stakeholders would be involved in managing school issues were badly needed if the Cameroon educational system was to be transformed to meet up with the deficiencies that characterized the period of centralization. In fact, the government of Cameroon had to accept that she could not foot the bill on education alone if the Cameroon school system was to be transformed, and the necessary finances made available to uplift the sector. As a result, the government had to carry out reforms to revamp the educational system in the domains of provision, support and management.

From the provision perspective, law $\mathrm{N}^{\mathrm{0}} 98 / 004$ of $14^{\text {th }}$ April 1998 was passed. This law on the educational guidelines for Cameroon asserted the government position on education. In matters of provision, this law in section 2 (lines 1,3) and section 12, recognized the roles of the state and other stakeholders in the provision and financing of education. With regards to support, the same law in section 32 (line 1), identified stakeholders "Educational Community" to partner in educational provisions. This support mechanism of the educational system was further boosted by decree No $2010 / 2047 / \mathrm{Pm}$ of $26^{\text {th }}$ February 2010 , which was meant to give the community a greater say in the management of schools, both primary and secondary, by permitting local collectives (Municipal Councils), the role to sponsor educational programmes, build schools, supply benches, provide minimum packages, supply subvention in cash and even employ and pay teachers. To ensure the participation of the community in supporting government action in the domain of financial provision, the government reinforced existing administrative instruments(Ministerial Circulars), on the functioning of the PTA, officially recognizing it as the financial linchpin of secondary schools (circulars $\mathrm{N}^{\mathrm{O}}$ 045/BI/1464/MINESEC/SG/DSAPPS of $13^{\text {th }}$ September 1996, and inter-ministerial circular $\mathrm{N}^{\mathrm{O}} 242 / \mathrm{L} / 1729 / \mathrm{MINEDUC} / \mathrm{MJS}$ of $25^{\text {th }}$ February 2008).

From a policy perspective, Decree $\mathrm{N}^{\mathrm{O}} 2001 / 41$ of $19^{\text {th }}$ February 2001, created the School Council or (SMB), to control, supervise and evaluate the way schools were managed at the school base level. In fact, article 23(1) of this 2001 law described the SMB as an organ of "supervision, advice, deliberation, control and evaluation of the running of secondary schools". In the same light, article 33 of the 2001 law, recognized school principals as head of secondary schools, with the responsibility of managing schools administratively, pedagogically, educationally and financially.

From the above, the reforms on educational decentralization carried out under the new regime, officially recognized school Principals, SMB chairpersons, and PTA presidents, as having a say in the running of public secondary schools. The various administrative instruments authorizing their functioning (Decree NO 2001/41 of $19^{\text {th }}$ February 2001, for school principals and the SMB), and the February $25^{\text {th }} 2008$ inter-ministerial circular for the PTA), attributed roles to them particularly in the domain of policy formation and implementation, financial, material and human resource management. 
However, a close analysis of the roles as stipulated in articles 23 and 34 of the 2001/041 of the 19/02/2001, Law for SMB and principals and the 2008 inter-ministerial circulars, for the PTA, show that these three stakeholders in some areas were given conflicting and /or were attributed the same roles. In fact, in some cases, these roles contradict, overlap, were ambiguous, paradoxical and difficult to apply. Such areas of ambiguity and non-clarity of roles made the role actors (Principals, SMB chairpersons, and PTA presidents) to perceive their roles differently, a situation which usually led to conflicts between them, as each sometimes performed the roles of others with the believe of performing their own roles. This study therefore is situated within the context of conflicting financial roles by stakeholders due to differences in perception, a situation which is leading to bickering, disagreement, tension and conflict over the management of financial resources in PSGS in the South West Region.

\section{The Problem, ObJeCtive ANd Hypothesis}

The main problem in this research is that of conflict between school principals, SMB chairpersons and PTA presidents (herein referred to as educational stakeholders) over their role in the management of finances in PSGS in the South West Region of Cameroon. Financial roles in this study could be said to include; the drawing, adoption and execution of school budget. Execution itself involves the collection, preservation and expending of funds derived from various sources such as state subventions, parents (registration and PTA levy), donations and legacies among others.

As a result of government decision to decentralize the source of school financing and the management of school funds, various legislations that authorized the existence or creation of the PTA and SMB also attributed them roles which in most cases overlapped, were complementary, contradicted or were conflicting. Evidence from both anecdotal and literature review (Khuzouyo 2008, Mbake 2013, Lifafe 2011, Onderi and Mokori 2012, 2013) have observed that where roles overlap or contradict, there is bound to be conflict in their execution, as each or all of the stakeholders perceived such roles as assigned to them, and in the cause of wanting to effect their execution, step on the roles of the other stakeholders, a situation that leads to conflict. Such conflicts usually took the form of disagreement, bickering, tension and overt fights, as each stakeholder jockey for the control of school funds.

A close investigation into these conflicts show they result from the gap existing between what is statutorily attributed or prescribed as roles and what some of these stakeholders perceive to actually be their roles, with regards to the collection and expending of funds in PSGS. This research captures the fact that this gap between prescribed and perceived roles is fundamentally responsible for the various conflicts in the management of funds in schools. Hence, the interest in this study.

The main objective of this study was to investigate whether differences in the way stakeholders perceive their financial roles are responsible for the conflicts that broke out amongst them in the management of financial resources in PSGS in Cameroon. The pertinent question, therefore, was: what is a relationship between differential perception of financial roles by stakeholders and conflict in the management of financial resources in PSGS in the South West Region of Cameroon?. The study thus hypothesize that: There is no significant correlation between differential perception of financial roles by stakeholders and conflict in the management of financial resources in PSGS in the South West Region of Cameroon.

\section{THEORETICAL BACKGROUND}

This study was guided by four theories. Agyris and Schön's 'Espoused Theory of Action' and 'Theory in Use' (1994) and as expounded by Naido (2005); MuzaferSherif and D. T. Campbell's ('Realistic Conflict Theory' (Campbell, 1965 and Sherif, 1966); Getzel's Behavioural or Social Science Theory (1957) and Freeman's (2004) Stakeholders' Theory. These theories have been used to explicate the link or relationship between perceived roles in financial resource management and conflict. While 'Espoused Theory of Action' and 'Theory in Use'(Naido. 2005) explain that conflicts arise when real or prescribed roles are set aside for those perceived, the Realistic Conflict Theory and Stakeholders' Theory explained conflicts which come as a result of clash of interest particularly when stakeholders are after scarce resources. In fact, as stakeholders clamour to control the scarce financial resources of schools, they are tempted to perceive the control of these resources as falling within their 
realm, irrespective of the various texts apportioning functions and attributing those roles to other stakeholders. On its part, Gezel's Behavioural or Social Science Theory (Getzel and Guba 1957, in Mbua, 2003) posits that conflicts among stakeholders result from the clash between nomothetic and idiographic behaviours. It states that organisations or schools have expectations (nomothetic dimension) which are being translated into roles. These roles are supposed to be executed by individuals (stakeholders or managers), who have their personal needs (idiographic dimension) or needs dispositions. Most often, when their personal needs are influenced by greed, these stakeholders instead of executing the expected needs of the organizations rather satisfy their own needs, even if what they execute as roles fall within the roles of other actors in the organisation (schools). A situation which often brings about conflict between these stakeholders and the organisation, or with other actors.

\section{Methodology}

This is a descriptive study based on a cross-sectional survey approach, adopting triangulated techniques as it relied on collecting and analyzing data using quantitative and qualitative strategies. The study involved 76 principals, 75 SMB chairpersons and 75 PTA presidents from 76 Public Secondary Grammar Schools in the South West Region of Cameroon. These categories of participants were selected for the study because of their involvement in the conception, and implementation of financial policies in their respective schools, and because they were practically involved in the management of financial resources in the targeted schools. The study employed the probability and non probability sampling approaches in multiple stages to come out with this sample. While nonprobability sampling technique, notably the purposive or judgmental sampling was used to select the South West Region for the study, the probability sampling technique was used to come out with the respondents. Concerning probability sampling, this was done in multi-stages while the stratified random sampling technique was used to proportionately include participants from all the administrative divisions in the South West Region, the simple random technique with the use of the table of random numbers was used in selecting the participating schools (and hence respondents) for each division of the South West Region.

The study used two data collection instruments, namely; the questionnaire (open and closed ended) and interview guide to capture quality information that represents principals, PTA presidents, and SMB chairpersons perception on all indicators of this study. Documentary evidence was used to corroborate or denounce the perception held by stakeholders with regards to their roles.

The questionnaire developed by the researcher to assess the indicators on perceived financial resource management roles was administered to 76 principals, 75 PTA presidents and 75 SMB chairpersons who participated in the study. All items were pre-coded on a 4 point Likert scale as Strongly Agree (SA), Agree (A), Disagree(DA) and Strongly Disagree (SDA). In addition, there were five openended questions requiring every participant to state whether roles they perceived to be theirs, were being performed by them or other stakeholders, and in case of the latter, stated what factors hinder them from carrying out their perceived roles, and what types of relationship developed with the other stakeholders who prevented them from performing their perceived roles?

The interview guide was used to carry out interviews with 45 participants of the study. These participants (15 principals, 15 PTA presidents, 15 SMB chairpersons) were randomly selected from amongst the 75 principals, 75 PTA chairpersons and 75 PTA presidents of participatory schools. These participants were interviewed on the issues at stake in this study.

Data collected from the field were being subjected to the Statistical Package for Social Sciences. (SPSS) version 25, which was used to compute frequencies and percentages. While, Content analysis was used to analyze the five open-ended item of the questionnaire, and the response from interview guide.

The hypothesis was verified using the Pearson Product Moment Correlation Analysis, with the index at 0.05 alpha level of significance (2-tailed). 
Differential Perception of Roles and Conflict in the Management of Financial Resources: The Case of Stakeholders in Public Secondary Grammar Schools in the South West Region of Cameroon

\section{FINDINGS}

\subsection{Perception of Financial Resource Roles by Principals}

Table1. Perception of Roles on the Management Financial Resources by Principals

\begin{tabular}{|c|c|c|c|c|c|c|c|}
\hline \multirow[t]{2}{*}{$\mathbf{s} / \mathbf{n}$} & \multirow[t]{2}{*}{ Statement } & \multicolumn{6}{|c|}{$\begin{array}{c}\text { Response Options, Frequencies (f) } \\
\text { and Percentages }(\%)\end{array}$} \\
\hline & & $\begin{array}{c}\text { SA/A } \\
\text { (f) }\end{array}$ & $\%$ & $\begin{array}{c}\text { DA/S } \\
\text { DA (f) }\end{array}$ & $\%$ & $\begin{array}{l}\text { Missing } \\
\text { data (f) }\end{array}$ & $\%$ \\
\hline 1 & I authorize the collection of school fees & 60 & 85.7 & 10 & 14.3 & & \\
\hline 2 & I authorize the collection of PTA fees & 16 & 22.9 & 52 & 74.3 & 2 & 2.8 \\
\hline 3 & I order the preservation and withdrawal of funds for school use & 64 & 91.4 & 6 & 8.6 & & \\
\hline 4 & I determine the allocation of funds for PTA use & 42 & 60.0 & 24 & 34.3 & 4 & 5.7 \\
\hline 5 & The management of PTA funds is my responsibility & 4 & 5.7 & 64 & 91.5 & 2 & 2.8 \\
\hline 6 & I order the expenditure of school/SMB funds & 62 & 88.6 & 8 & 11.4 & & \\
\hline 7 & I am supposed to take part in the budgeting of the school & 68 & 97.1 & & & 2 & 2.8 \\
\hline 8 & I participate in the approval/ adoption of the school budget & 70 & 100. & & & & \\
\hline
\end{tabular}

Results on Table 1 showed that as far as perception of roles on the management of financial resources was concerned, principals' response rates were as follows:

- $85 \%$ perceived that they authorized the collection of school fees.

- $22.9 \%$ authorized the collection of PTA fees.

- $91.4 \%$ ordered the preservation and withdrawal of funds for school use.

- $60 \%$ determined the allocation of funds for PTA use.

- $\quad 5.7 \%$ managed PTA funds in their locality.

- $88.6 \%$ ordered the expenditure of school/ SMB fund.

- $\quad 97.1 \%$ took part in budgeting of the school.

- $100 \%$ participated in the approval and adoption of the school budget.

\subsection{Perception of Financial Resource Roles by PTA Presidents}

Table2. Perception of Roles on the Management of Financial Resources by PTA Presidents

\begin{tabular}{|c|c|c|c|c|c|c|c|}
\hline \multirow[t]{2}{*}{$\mathbf{s} / \mathbf{n}$} & \multirow[t]{2}{*}{ Statement } & \multicolumn{6}{|c|}{$\begin{array}{c}\text { Response Options, Frequencies (f) and } \\
\text { Percentages }(\%)\end{array}$} \\
\hline & & $\begin{array}{c}\text { SA/A } \\
\text { (f) }\end{array}$ & $\%$ & $\begin{array}{c}\text { DA/SD } \\
\text { A (f) }\end{array}$ & $\%$ & $\begin{array}{l}\text { Missing } \\
\text { data (f) }\end{array}$ & $\%$ \\
\hline 1 & I authorize the collection of school fees & 6 & 10.0 & 52 & 86.7 & 2 & 3.3 \\
\hline 2 & I authorize the collection of PTA fees & 50 & 83.3 & 6 & 10.0 & 4 & 6.7 \\
\hline 3 & I order the preservation and withdrawal of funds for school use & 2 & 3.3 & 56 & 93.3 & 2 & 3.3 \\
\hline 4 & I determine the allocation of funds for PTA use & 58 & 96.7 & 2 & 3.3 & & \\
\hline 5 & The management of PTA funds is my responsibility & 54 & 90.0 & 4 & 6.7 & 2 & 3.3 \\
\hline 6 & I order the expenditure of school/SMB funds & 6 & 10.0 & 50 & 83.3 & 4 & 6.7 \\
\hline 7 & I am supposed to take part in the budgeting of the school & 58 & 96.7 & 2 & 3.3 & & \\
\hline 8 & I participate in the approval/ adoption of the school budget & 52 & 86.7 & 6 & 10.0 & 2 & 3.3 \\
\hline
\end{tabular}

Results on Table 2 showed that as far as perception of roles on the management of financial resources is concerned, PTA Presidents' response rates were as follows:

- $10.0 \%$ perceived that they authorized the collection of school fees.

- $83.3 \%$ authorized the collection of PTA fees.

- $3.3 \%$ ordered the preservation and withdrawal of funds for school use.

- $\quad 96.7 \%$ determined the allocation of funds for PTA use.

- $90.0 \%$ managed PTA funds in their locality.

- $10.0 \%$ ordered the expenditure of school/ SMB fund.

- $96.7 \%$ took part in budgeting of the school.

- $86.7 \%$ participated in the approval and adoption of the school budget. 


\subsection{Perception of Financial Resource Roles by SMB Chairperson}

Table3. Perception of Roles on the Management of Financial Resources by SMB chairpersons

\begin{tabular}{|c|c|c|c|c|c|c|c|}
\hline \multirow[t]{2}{*}{$\mathbf{s} / \mathbf{n}$} & \multirow[t]{2}{*}{ Statement } & \multicolumn{6}{|c|}{$\begin{array}{c}\text { Response Options, Frequencies (f) and } \\
\text { Percentages }(\%)\end{array}$} \\
\hline & & \begin{tabular}{|c|} 
SA/A \\
(f)
\end{tabular} & $\%$ & \begin{tabular}{|l|} 
DA/S \\
DA (f)
\end{tabular} & $\%$ & $\begin{array}{l}\text { Missing } \\
\text { data (f) }\end{array}$ & $\%$ \\
\hline 1 & I authorize the collection of school fees & 46 & 65.7 & 20 & 28.6 & 4 & 5.7 \\
\hline 2 & I authorize the collection of PTA fees & 26 & 37.1 & 38 & 54.3 & 6 & 8.6 \\
\hline 3 & I order the preservation and withdrawal of funds for school use & 10 & 14.3 & 58 & 82.9 & 2 & 2.9 \\
\hline 4 & I determine the allocation of funds for PTA use & 2 & 2.8 & 62 & 88.6 & 6 & 8.6 \\
\hline 5 & The management of PTA funds is my responsibility & 4 & 5.7 & 62 & 88.6 & 4 & 5.7 \\
\hline 6 & I order the expenditure of school/SMB funds & 40 & 57.1 & 24 & 34.3 & 6 & 8.6 \\
\hline 7 & I am supposed to take part in the budgeting of the school & 54 & 94.2 & 8 & 2.9 & 8 & 2.9 \\
\hline 8 & I participate in the approval/ adoption of the school budget & 62 & 88.6 & 6 & 8.6 & 2 & 2.8 \\
\hline
\end{tabular}

Results on Table 3 showed that as far as perception of roles on the management of financial resources is concerned, the following rate of SMB chairpersons were registered:

- $65.7 \%$ perceived that they authorized the collection of school fees.

- $37.1 \%$ authorized the collection of PTA fees.

- $14.3 \%$ ordered the preservation and withdrawal of funds for school use.

- $2.8 \%$ determined the allocation of funds for PTA use.

- $5.7 \%$ managed PTA funds in their locality.

- $57.1 \%$ ordered the expenditure of school/ SMB fund.

- $94.2 \%$ took part in budgeting of the school.

- $88.6 \%$ participated in the approval and adoption of the school budget.

5.4. Areas of possible conflicts between the principals, PTA presidents and SMB chairpersons based on their perception

Table4. Areas in the Management of Finances where Conflicts may arise

\begin{tabular}{|l|l|c|c|c|}
\hline \multicolumn{1}{|c|}{$\begin{array}{c}\text { S/n } \\
\text { Percentage for SA/A }\end{array}$} & \multicolumn{1}{|c|}{$\begin{array}{c}\text { Principals } \\
\text { PTA }\end{array}$} & $\begin{array}{c}\text { PMB } \\
\text { Presidents }\end{array}$ & $\begin{array}{c}\text { Shairpersons } \\
\text { ChA/A }\end{array}$ \\
\cline { 3 - 5 } & & SA/A & SA/A \\
\hline 1 & I authorize the collection of school fees & 85.7 & 10.0 & 65.7 \\
\hline 2 & I authorize the collection of PTA fees & 22.9 & 83.3 & 37.1 \\
\hline 3 & I order the preservation and withdrawal of funds for school use & 91.4 & 3.3 & 14.3 \\
\hline 4 & I determine the allocation of funds for PTA use & 60.0 & 96.7 & 2.8 \\
\hline 5 & The management of PTA funds is my responsibility & 5.7 & 90.0 & 5.7 \\
\hline 6 & I order the expenditure of school/SMB funds & 88.6 & 10.0 & 57.1 \\
\hline 7 & I am supposed to take part in the budgeting of the school & 97.1 & 96.7 & 94.2 \\
\hline 8 & I participate in the approval/ adoption of the school budget & 100. & 86.7 & 88.6 \\
\hline
\end{tabular}

Results on Table 4 showed that, in the area of financial management, conflicts may arise between the following stakeholders:

- Between Principals (85.7\%) and SMB chairpersons (65.7\%) in authorizing the collection of school fees.

- Between Principals (60.0\%) and PTA presidents (96.7\%) in determining the allocation of funds for PTA use.

- Between Principals (88.6\%) and SMB chairpersons (57.1\%) in ordering expenditure of school and SMB funds.

- Amongst Principals (97.1\%) and PTA presidents (96.7\%) and SMB chairpersons (94.2\%) in taking part in budgeting school funds.

- Amongst Principals (100\%) and PTA presidents (86.7\%) and SMB chairpersons (88.6\%) in participating in the approval and adoption of the school budget. 
Differential Perception of Roles and Conflict in the Management of Financial Resources: The Case of Stakeholders in Public Secondary Grammar Schools in the South West Region of Cameroon

\subsection{Content Analysis of Interview with Stakeholders}

Table5. Content Analysis of Interview Guide showing opinion held by Stakeholders on their Perceived Roles in the Management of Financial Resources

\begin{tabular}{|c|c|}
\hline Stakeholders & In your Opinion what are your Roles in the Management of Financial Resources? \\
\hline PRINCIPALS & $\begin{array}{l}\text { - } \quad \text { I supervise and authorize expenditures on rubrics. } \\
\text { - } \quad \text { I prepare the budget and ensure it is adopted. } \\
\text { - } \quad \text { Ensure funds are kept by the Bursar. } \\
\text { Ensure the Bursar and financial secretary sign the withdrawal slips with the } \\
\text { PTA presidents whenever need for PTA funds arises. } \\
\text { - } \quad \text { Ensure the execution of the budget and that this is done by law. } \\
\text { - } \quad \text { Payment of PTA teachers / auxiliary staff. } \\
\text { - Ensure that PTA funds are safely preserved by seeing and keeping PTA deposit } \\
\text { slips. }\end{array}$ \\
\hline $\begin{array}{l}\text { SMB } \\
\text { CHAIRPERSONS }\end{array}$ & $\begin{array}{l}\text { - Assist the principal in the management of school finances. } \\
\text { - } \quad \text { Ensure transparency and accountability in the management of both PTA and } \\
\text { SMB funds by both the PTA presidents and principals. } \\
\text { - } \quad \text { Ensure that money allocated for school use is adequately expended. } \\
\text { - } \quad \text { Ensure that funds (SMB or PTA) are safely preserved. } \\
\text { - } \quad \text { Supervise, monitor and control all expenditures affected by the principal and } \\
\text { PTA presidents. } \\
\text { - } \quad \text { Supervise projects executed by principals. } \\
\text { - } \quad \text { Report cases of management of funds by school principals or PTA presidents. } \\
\text { - } \quad \text { Participate in budgeting (preparation and adoption). }\end{array}$ \\
\hline $\begin{array}{l}\text { PTA } \\
\text { PRESIDENTS }\end{array}$ & $\begin{array}{ll} & \text { Collect and preserve PTA funds. } \\
\text { - } & \text { Propose and execute PTA budget after adoption. } \\
\text { - } & \text { Order expenditure of PTA funds. } \\
\text { - } & \text { Execute PTA budget with other PTA executive members. } \\
\text { - } & \text { Provide financial assistance to schools to purchase didactic and other materials. } \\
\text { - } & \text { Pay PTA teachers and auxiliary staff. } \\
\text { - } & \text { Disbursement of funds for projects and materials. }\end{array}$ \\
\hline
\end{tabular}

Analysis of results on table 5 shows there are areas where all three stakeholders claim the right to perform the same roles like the others. Such areas of similarity of roles either because they are attributed or wrongly perceived are usually zones of conflict between them.

Results on Tables 1, 2, and 3, showed that all stakeholders (Principals, PTA Presidents and SMB Chairpersons), from their perception claim to have important roles to play in the management of financial resources. These responses were further corroborated by qualitative data from the content analysis of interviews carried out (Table 5). Where all three or two of the stakeholders claimed they had more than 50\% rights to perform the same roles, was an indication that conflicts may result as each struggled to perform this role. Such areas where conflicts in the management of financial resources occurred are exhibited in Table 4 and the analyses that followed.

\subsection{Hypothesis Testing}

Null hypothesis (Ho). There is no correlation between deferential perception of financial roles by stakeholders (principal, PTA presidents and SMB chairpersons) and conflict in the management of financial resources in schools.

Alternative hypothesis (Ha). There is a significant correlation between differential perception of financial roles by stakeholder (principals, PTA presidents and SMB chairpersons) and conflicts in the management financial resources in schools.

The independent variable for this hypothesis was differential perception of financial roles by stakeholders while the dependent variable was conflict in the management of financial resources in schools.

The scores for the independent variable (Y-scores) represented the 200 scores on differential perception of financial resource roles by stakeholders, while the scores for the dependent variable (Xscores), represented the 200 scores by the stakeholders on conflicts in their (financial resources) management in schools. 
The statistical technique used to verify this hypothesis was the Pearson Product Moment Correlation Analyses. The results are presented on the Table 6 that follows.

Table6. Summary of SPSS Analysis for Hypothesis Testing

\begin{tabular}{|l|c|c|c|c|}
\hline \multicolumn{1}{|c|}{ Variables } & $\sum \mathbf{X}$ & $\sum \mathbf{X}^{\mathbf{2}}$ & & \\
\hline & $\sum \mathrm{Y}$ & $\sum \mathrm{Y}^{2}$ & $\sum \mathrm{XY}$ & $\mathrm{r}_{\mathrm{xy}}$ \\
\hline Differential perceptions of financial resource roles & 5096 & 68217 & 46785 & $0.79^{*}$ \\
\hline Conflicts in their management in schools & 4009 & 37914 & & \\
\hline
\end{tabular}

alevel $=0.05, \mathrm{df}=198$, critical $\mathrm{r}_{\mathrm{xy}}=0.073$

At alpha level of significance of 0.05 , with degree of freedom $=198$, ther- critical value is 0.073 .

Since $r_{x y}$-computed value (0.79) is greater than $r_{x y^{-}}$critical value (0.073), the null hypothesis was rejected following the decision rule.

Inference led to the conclusion that, there is a correlation between differential perceptions of financial resource roles by stakeholders and conflict in their management in schools.

Table7. Determination of Magnitude of Correlation

\begin{tabular}{|l|l|l|}
\hline Magnitude & Range & Max. Value \\
\hline High & $0.68-1$ & \\
Moderate & $0.34-0.67$ & \\
\hline Low & $0-0.33$ & \\
\hline
\end{tabular}

Since the $\mathrm{r}_{\mathrm{xy}}$ - computed value (0.79) lies within 0.68 and 1 , the magnitude of correlation between the two variables of interest is high (Table 7). That is, there is a high correlation between differential perception financial resource roles by stakeholders and conflicts in their management in schools.

\section{DISCUSSION OF FINDINGS}

This shall be made based on the objectives of the study. To better discuss the research findings and for proper verification of the lone hypothesis under investigation, the roles under investigation shall be grouped into three categories:

"Exclusive, Shared/Overlapping, and Contested roles."

- Exclusive Roles: these are roles officially recognized as attributed to a particular stakeholder and therefore neither clash nor are contested by the others.

- Shared Roles: According to Onderi and Makori, (2012 and 2013), these are roles claimed to be performed by both or (three in the case under study) stakeholders either because they are officially being attributed by the various texts that define their roles and hence officially overlap or are shared; and

- Contested Roles: These are roles in which the stakeholders in question out of their own perception simply assume/arrogate.

Whether attributed or arrogated, performing the same role/roles by all three or just two of the stakeholders are usually soft or fertile grounds for disagreements, bickering, tension and conflicts. With regards to the objective of this study, attention will be on shared, overlapping and/or contested roles. However, explication in defence of exclusive roles will also be made where and when necessary.

\subsection{Differential Perception of Financial roles by Stakeholders and Conflict in the Management of Financial Resources in PSGS in the SWR of Cameroon}

Using budgeting (preparation, and adoption) and execution (authorization to collect funds/receiving, its preservation/keeping and expending) as our indicators, evidence from this research supports this result, that is, a high correlation between differential perception of financial roles and conflicts in the management of financial resources (Mbake, 2013) says the "roles of stakeholders in financial matters in schools could be divided into receiving, keeping and expending of funds." 
Research findings from anecdotal and literature reviewed show that all three categories of stakeholders rightly or wrongly perceive these roles (budgeting, receiving, keeping and expending) of funds as falling within their realm of competence (See table 1,2 and 3 above).

As earlier stated, within the context of this study, roles will be categorized or grouped into "exclusive" and "overlapping, shared or contested" roles. The following roles were considered as exclusive:

- The authorization to collect PTA funds

- The management of PTA funds.

The research findings show that these two management roles were accepted by all three stakeholders as the preserve of the PTA presidents. An examination of the tables cited above show that all the other roles were "claimed" to be the prerogative of more than one stakeholder. Our discussion therefore, will be focused on overlapping, shared and contested roles. Table 4 presents the opinions or perception of stakeholders put comparatively with regards to their financial resources roles in the management of schools. These perceptions were scored in percentages. Where stakeholders had above fifty percent claim over the right or duty to execute the same roles, was an indication that such roles either "overlapped", or were joint, shared and /or contested.

Results from Table 4 portrayed these roles as follows:

- Between Principal and SMB chairpersons

$>$ Authorization to collect school fees; Principal (85.7\%) and SMB chairperson (65.7\%)

$>$ Ordering the expenditures of school/ SMB funds; Principal (88.6\%) and SMB chairperson $(57.1 \%)$

- Between principal and PTA presidents

$>$ Costing/allocation of funds for PTA projects; Principals (60\%) and PTA presidents $(96.7 \%)$

- Between principals, PTA presidents and SMB chairperson

$>$ Budgeting; Principals (97.1\%), PTA Presidents (96.7\%), and SMB chairpersons (94.2\%)

$>$ Approval and adoption of budget: Principals (100\%) PTA Presidents (86.7\%) and SMB chairpersons $(88.6 \%)$

The results from the above findings showed that on matters concerning finance, the principals and SMB chairpersons arrogated the role to authorize the collection of school fees, and to order its expenditures. The Principals and the PTA presidents claim to have the right to do costing of and allocate funds for various PTA projects, while all three stakeholders claimed to have powers to do budgeting, approve and adopt the budget. Content analysis (Table 5) of interviews held with Principals, PTA Presidents and SMB Chairpersons support these findings above, as all three groups of stakeholders not only claim they had financial roles to perform, but were able to identify some of the financial roles that are performed or expected to be carried out by other stakeholders.

With regards to Principals, content analysis of interviews held with them (Table 5), showed a majority claimed their financial roles were, to solicit for PTA funds, ensure school funds are safe guarded by the bursar, ensure withdrawals of funds for expending by bursar and financial secretaries, Prepare the school budget and get it executed, authorize all expenditures in school, make suggestions to PTA on how to expend their budget, supervise through the bursar, the withdrawal and use of PTA funds, ensure that PTA funds are safely preserved by safely keeping a copy of the deposit slips of PTA funds and ensuring that the execution of their finances is done according to the law.

On their part SMB chairpersons (Table 5) claim their financial roles included; assisting Principals in the management of school finances, checking receipts of expenditures, making sure funds are available for payment of PTA teachers, participating in budgeting and its adoption, approval of all expenditures, supervising of projects executed by the Principal and PTA Presidents, and sourcing for funds to support school activities, in case of needs. While the PTA Presidents on their part (Table 5), 
claimed their financial roles were collection, preservation and judicious expending of PTA funds, planning of the school budget (including those of the PTA) with the principals, make money available, when there are projects to execute, provide financial assistance to schools for the purchase of didactic materials or purchase them themselves, execute PTA budgets, participate in budgeting and oversee its adoption. From the above, it would be said that all three stakeholders perceived they had serious financial roles to play in schools. From the content analysis of results gotten from interviews, it is obvious that there are areas where roles "Overlap" or are "Contested" either because they are legally attributed, hence share roles, or they are not properly (poorly) perceived roles.

Not only did stakeholders identify roles perceived to be theirs, they also stated those financial roles they felt were theirs, but which other stakeholders arrogated or performed. Extracting from Table 5, principals felt rightly or wrongly that they had the right to pay PTA teachers, but these rights were also being claimed by the PTA presidents. On the other hand, principal questioned the right of PTA presidents to withdraw and spend PTA funds without the knowledge of these Principals (through their Bursars). By questioning this role, principals implicitly felt they should have a say in the execution of this role. It should be noted that such roles where two or three stakeholders had interest or claimed to have the right to execute but felt others were performing were usually areas of conflict between these stakeholders. In fact, the importance of finance as resources in the effective management of schools cannot be underestimated. Agentha (1984) had stated that "the success of any secondary school depends on the resources available to it. Money is very important in this respect because by it all vital elements in the school can be obtained such as buildings, purchase of equipment, payment of teachers' salaries, allowances and running expenses". Because of the centrality of money in a successful school system, it is not surprising that the various stakeholders clamour for its control and expending and as a result, misperception of roles, infringement on the roles of others, disagreements over who has the authority to expend, situations which all led to conflicts abound. MuzeferSherif (in Tajfel and Turner, 1979) in stating his Realistic Conflict theory says that conflicts are borne out of competition for scarce resources. In fact, he posits that in organizations "opposed groups interests in obtaining scarce resources promote competition... conflicting interest develops through competition into overt social conflicts." In the PSGS system in Cameroon in general and the SWR in particular, the financial resources to be managed by the principals, the PTA presidents are scarce and this often brings competition and hence conflicts between them.

This supports the findings of Lifafe (2011), and Morfaw (1999) which cites wrangling over the execution of financial roles and control of scarce financial resources by some of these stakeholders involved in this study as a source of conflicts in schools. Baumeistr and Vohs (2007), posit that the Realistic Conflict Theory describes how perceived competition for limited resources can lead to hostility between groups.

An examination of section III, paragraph V of February $28^{\text {th }} 2008$ Circular letter on the running of the PTA in PSGS, states however that principals have the right to follow up all withdrawals of PTA funds through their Bursars, and hence question any withdrawals and expending of such funds if this is done without their knowledge because as technical advisers they are expected to know the intended use of the withdrawals of such funds. On the other hand this and other statutory documents on the PTA do not permit the principals to pay PTA and other auxiliary staffs as most principals indicated was their role. Arrogating such role must have been a misperception probably influenced by article 34 (line 10 and 11) of decree No 2001/041 of $19^{\text {th }}$ February 2001, which states principals must "have authority over all staff in the school," and that principal "assesses all staff under his authority." Most Principals believe that having authority and assessment cannot be effective without control over remuneration, particularly with PTA teachers and auxiliary staff.

The evidences above show that as far as the management of finance is concerned, there are some grey areas with regards to stakeholder's roles. Khuzwayo (2007) says grey areas or where roles overlap are usually fertile grounds for misunderstandings, tensions and conflicts. Lifafe (2011), Mbake (2013) and Onderi and Makori (2012), support this view. In fact (Table 5) on interviews with stakeholders actually revealed some areas of possible conflict between principals and PTA Presidents.

Deducing from the table, other conflicts on financial roles from the principals' perspective are centred on; the management of PTA expenditures. Most principals blamed PTA presidents for withdrawing 
PTA funds without their (Principal's) knowledge, or approval, or signature of the Bursar. They went further to accuse PTA presidents for withdrawing PTA funds for personal use. In the words of Principal A (in a school in Fako Division), "My PTA president does not respect the text (Feb.25 2008 circular letter).He and the members of the PTA Exco, make withdrawals and carry out expenditures without my knowledge, and without the Bursar co-signing the withdrawal cheque. When I question them they said, that they were told by the Divisional Delegate that the PTA was an independent association and therefore had a right to operate and with no interference from the principal or the SMB chairman"

On their part, PTA presidents accused principals for collecting and using PTA funds, and that the PTA presidents are supposed to be the sole collectors of PTA money. They also blamed principals for intervening in the management of PTA funds. In fact one PTA president (school I in Ndian Division) declared. "My principal collects money for PTA, since the treasurer is hardly around and since this period of collecting fees coincides with when we are picking cocoa. But later, when I asked that the money should be transferred to the PTA account, he said we should give him time and that he has used part of the money for the burial of his mother, and promised he was going to pay back. After one month, instead of paying back, he rather presented us receipts of things he claims he had used the money to do on behalf of the PTA. What is surprising is that some of the things we did not budget for nor authorize him to expend. Sir, last year, this same "Sango" (the principal) collected money to paint the school, which he did only part. He also took money that he was going to buy books for the library, which we saw only a few. He also took money that he was going to campaign for teachers, but we saw no teacher..."

Another case of principal interfering with PTA funds was reported by an SMB chairperson (school K in Manyu Division). ".... when I attended a seminar in Kumba, actually about two years ago, Conflicts were reported in some schools by the PTA presidents. We were told of the case of a principal who when he collects PTA money (levy), he takes upon himself to use the money without consulting the school management chairperson or the presidents (PTA) and this in fact poses a lot of conflict. I can also remember the situation of a school in Ndian Division (name withheld), where the PTA president and the SMB chairperson did not agree with the principal. I know when money is concerned there are some areas where some people have a very huge appetite".

This type of scenario was recorded in a good number of schools particularly in the rural areas where some principals actually posed as managers of both the school and PTA funds.

With regards to the SMB chairpersons, both the Principal and PTA presidents declared that conflicts usually occurred when SMB chairpersons side-stepped their purely controlling, monitoring, supervisory and evaluation roles, and got involved in the day to day management of the finances of either the PTA or the school.

\section{CONCLUSION}

Based on the findings of this research, it has been concluded that differences in the perception of financial roles were largely contributing in conflicts in the management of resources. In fact the correlation between differences in perception of financial roles by stakeholders and conflicts in the management of resources after verification of hypotheses was high or significant (rxy computed value $0.79)$.

Findings also revealed that the perceptions stakeholder held of their financial roles lead to serious contest and conflicts in the management of financial resources in PSGS in the SWR of Cameroon. Anecdotal and literature review had indicated that where stakeholders claimed to perform the same roles were likely zones of conflicts. Such zones as outlined in this research and are also found in Table 4, include: 1) between principals and SMB chairpersons i.e., who controls SMB funds (authorize the collection and expending of school fees. 2), who between PTA and principals control the management of PTA funds (authorization, collections, preservations, withdrawals, and expending). 3) Who between Principals, PTA presidents and SMB chairpersons does budgeting? It should be noted that the SMB chairpersons, PTA presidents and principal are all part of the budgeting and approval team of PSGS in the SWR of Cameroon. 
Research findings have shown the percentage claim of responsibility by the various stakeholders. However with regards to the control of SMB funds, the authorization to collect funds in principle comes after the projected budget of the school has been endorsed by the SMB chairperson at the end of the school year. Such projected budget must be co-signed by the SMB chairperson, the bursar and the school principal. The day to day collection of school fees is the responsibility of the principals which he does through instrumentality of the school bursar. He (principal) orders expenditures and authorizes all payments. This role has been contested by some SMB chairpersons who have misunderstood the mandate accorded them in article 23(1) of Decree No 2001/041 of 19/2/2001 wherein they are to act as supervisors, advisers and monitors, to mean getting involved in the direct/day to day management of the resources of the schools. This supports Onderi and Makori (2013), view that "lack of delineation between strategic management and day to day management of schools is a source of conflicts" between stakeholders. The position of the principal is supported by article 34 (lines $8 \& 9$ ) of the decree cited above, whose line (8) states principals "prepareallowances ..." and line (9) "orders expenditures."

Concerning budgeting research findings indicate that all three stakeholders indicated their involvement in budgeting and adoption of projects (Tables 4). While decree no 2001/041, Article 23(1.3), article 34 (6), links the SMB and the principal to budgeting, article 23(2), article 34(6) of the same decree involves them with conception and adoption of school projects. However the February 25, 2008 circular, part III, paragraph (3) by linking PTA projects to the school projects, is indicative of the fact that all three have a role on its budgeting, and approvals. However, with regards to control of PTA budget, part III paragraph 4 (5), of the February 25 2008, circular positions the principals to monitor the banking of PTA funds, by compelling the PTA hand copies of all deposits "tellers or slips" transactions made in the bank to principals, and that all withdraws of the PTA funds be cosigned by the Bursar. Any attempt by PTA presidents to deny principals this right obviously subjects them to conflicts with school principals.

This provisions made by February $25^{\text {th }} 2008$ circular letter is being perceived by some principals as having been given the mandate to control the management of PTA funds. Meanwhile most PTA presidents either outrightly deny this role to principals or are not comfortable with it as expressed by some of them. In fact most PTA presidents when interviewed on this matter showed open disgust and felt it was a sign that government did not trust them, as the PTA president (college B in Fako Division), stated, "Asking the Bursar to co-sign withdraws of the PTA fund is an abuse on the PTA." The PTA is registered and recognized as an independent organization, having as members parents whose children attend a school, and who out of their free will come together to assist their children by choosing to develop certain aspects of the school. Asking that we present copies of deposit slips of money we put in the bank to the principal or that the Bursar co-signs any withdrawal slips "cheques" made by the PTA gives the principals enormous powers to monitor our activities."

PTA presidents however fail to understand the sprit behind this statutory order, which is found in the preamble of the February 25, 2008 circular, and which centres its argument on financial abuses in the form of misappropriation of PTA funds, which has characterized the management of PTA since its inception.

Other findings with regards to conflicts over perception of roles and conflicts in the management of financial resources were centred on the claims by some principals that they determine the projects to be executed by the PTA and allocate or determine the amounts needed for such projects. Principal as technical adviser could advice on the needs of the school, stating which of these were priorities needing the intervention of the PTA. No statuses give principals the right to determine what amount of money should be allocated to such projects. This is the prerogative of the PTA.

Also, the fact that most SMB chairpersons by $(57.1 \%$, Table 4$)$ claimed they had the right to order expenditure, is indicative of the fact that they misperceive their roles, as decree 2001/041 article 34(9), is categorical as it states that Principals "orders expenditures".

\section{RECOMMENDATIONS}

This study has helped to bring out some of the salient causes of conflicts from a perceptual point of view witnessed in the management of PSGS amongst school principals, SMB chairpersons and PTA 
presidents. It has demonstrated that even though statutory documents exist spelling out the roles of these stakeholders, the mere existence of these documents are inadequate particularly if these stakeholders are not adequately educated of their functions. It has demonstrated theweaknesses that exist in some of these statutory documents, particularly with regards to overlapping roles, situations which orchestrate conflicts in PSGS. Based on the above, the study has made useful recommendations on how roles could be smoothened, so as to reduce future conflicts and improve on educational outcomes. The recommendations of this study have policy implications to school administrations and educational managers. Based on the findings and considering the conclusion drawn, the following recommendations were prescribed.

The Government of Cameroon should come with a comprehensive document on school governance or management like the South African School Acts (SASA), or the Nigerian National Policy on Education (NNPE), with the roles of all stakeholders written out clearly.

That such document should be made available to all stakeholders. Principals should be given copies upon their appointments. Copies should be made available to PTA presidents and SMB chairpersons upon their elections respectively. This single document with roles of all stakeholders will permit them read their roles and those of the others when need arises. This comprehensive text on roles will help clarify some of the ambiguities and roles repeating in the separate legal instruments on the functioning of the School Council and the PTA.

In addition, since current principals may find it difficult going back to schools to acquire these knowledge, the Faculty of Education in synergy/agreement with the regional and divisional delegations of secondary education could organize seminars and workshops for educational administrators and other stakeholders on what should constitute their roles and how to execute these roles so as to avoid conflicts.

To avoid conflicts with PTA presidents, the management of PTA funds which has become indispensable in running schools, due to diminished state subventions could be broken down into two categories (Investment Projects and Pedagogic support). Investment projects will include items like constructions of all types (building, benches, tables, playground) etc. and Pedagogic support will include financial assistance on issues like (laboratory reagents and glass wares, computers and accessories, seminars, PTA and auxiliary staff remuneration, health and administrative support) etc. To prevent future clashes, the PTA presidents and their bureau, should handled investment projects, while funds for pedagogic support which is more technical, be placed under the supervision of the principals who with committee of teachers specialized in the domains concerned, should be given the authority to manage the funds on pedagogic support. This will help to prevent the conflicts witnessed between principals and PTA presidents over the management of those aspects which are more technical and professional within their budget.

Good Governance. One of the main reasons for the inclusion of stakeholders in the management of schools had been to encourage collaborative and participative management in which all school managers will work as collaborative stakeholders to give schools the impetus they deserve. The government through the Regional and Divisional Delegation should ensure that good governance is practiced in PSGS, by guaranteeing that there is transparency, accountability, collective decision making and respect of the rule of law. With respect of the rule of law, where stakeholders do not perform their duties or step on the duties of others, such matters should be resolved judicially so as to serve as examples to future defaulters.

\section{REFERENCES}

[1] Adeogun, A.A. (2002). Economics of Education. Lagos: Oluntenji Press and Publisher.

[2] Agentha, J. A. (1998). Towards a system approach to the planning of secondary education in Nigeria. In S. Adesina and S. Ogunsau (eds) Secondary education in Nigeria. Ile-Ife. University of Ile Press Ltd 227243.

[3] Argyris, C and Schon, D. (1994).Theory in Practice and Theory in Use: increasing Professional effectiveness. San Francisco: Josey-Boss.

[4] Ajayi I.A. \&Ayodele, J.O. (2001).Introduction to Education Planning. Administrative and Supervision. Oshodi, Lagos: Yemi Prints. 
[5] Akumah, E. \&Gana, D.R. (2005) Deregulating the Provision and management of education in Nigeria. In Akpa, G.O., Udoh S.U., Fagbamiye, E.O. (EDS), Deregulating the Provision and management of Education in Nigeria. Jos. NAEAP.

[6] Ayuk, M. A. (2012). The perception of the influence of stakeholders' contribution in providing quality education.The case of Buea municipality schools.Unpublished M.ED Theses, University of Buea.

[7] Baumerster, R. F. and Vohs (2007) Eds. Encyclopaedia of Social psychology EBSCO Publishing e Book collection (EBSCOHOST), University of San Francisco.

[8] Besong, J.B, (2013) A Comparative Study of Administrative efficiency of Principals in Public and Private Secondary Schools in Maroua, Far North Region, Cameroon. In International Journal of Business and Management; Vol: 8 No. 7:2013.

[9] Cambell, R.P, Carbally, J.F, and Nustrand, R.O (1983).Introduction to educational administration. $\left(6^{\text {th }}\right.$ Edition) Boston. Allyn and Bacon Inc.

[10] Campbell, D. T (1965).Ethnocentric and other altruism and counter- hedonic components in human culture.Journal of Social Issues: 28, 21-27.

[11] Freeman, R.E (2004), “A Stakeholder Theory of modern Corporation”, Ethical theory and Business, $7^{\text {th }}$ edition.

[12] Fonkeng, E. G. (2006).The history of education in Cameroon, 1844-2004.New York: Edwin Mellen Press.

[13] Getzel, J. W and Guba, E. G (1957).“School Behaviour and Administrative Process."School Review. Vol. 66 рр 423-441.

[14] Khuzwayo, S. (2007).Role Relationships of school Governance Body Chairpersons and Principals in school Governance in selected primary and secondary schools in the Kwamashu area.

[15] Lifafe, M. L. (2011). Role conflict amongst secondary school principals and parent teachers, association executives: the case of public secondary schools in the south-west region of Cameroon. Unpubished $\mathrm{M}$. ED thesis. University of Buea. Cameroon.

[16] Mbake, H. L. (2013). Evaluating the Effectiveness of School Management Boards in Public Secondary Grammar Schools in Fako Division. Unpublished MED Thesis. University of Buea, Cameroon.

[17] Mbua, F.N. (2002): Educational financing; Issues and perspectives,. Presprint Ltd. Limbe. Cameroon.

[18] Mbua, F.N. (2003). Educational Administration: Theory and Practice: The Management of organization and individuals. Limbe: Design House, 2003

[19] Morfaw, R. (1999). A Hand Book on Pedagogic Inspection in Primary Schools.A Guide to StudentTeachers, Teachers, Inspectors, and Education Administrators. Kumba: Education Research Centre.

[20] Naidoo, J.O. (2005). Educational Decentralization and School Governance in South Africa; Policy and Practice. International Institute for educational Planning, (UNESCO)

[21] Ndongko, T.M. (1989). A handbook for secondary school administration. Nigeria; Hienemann Educational Book Ltd.

[22] Onderi, H and Makori, A. (2012).Differential Perceptions, Challenges, Conflicts and Tensions in the Role of Board of Governors (BOG) and Parent-Teacher Association (PTA) in Sub-Saharan Africa. A case of Kenyan Secondary Schools. Retrieved from http//www.interesjournals.org/ER.

[23] Onderi, H. and Makori, A (2013), challenges in Achieving effective school leadership and management in Kenya; A case of the Role of BOGs and PTAs in the Kisi country. International Journal of Advanced Research in Management and social sciences (ISSN: 2278-6236). www.garph.co.uk.pp 263-285.

[24] Republic of Cameroon (2008). Circular Letter No. 07/08/MINESEC/CAB of 25 ${ }^{\text {th }}$ February 2008 to lay down the terms and conditions of running Parent Teacher Association in Government Secondary Educational Establishments.

[25] Republic of Cameroon (2008).The 1996 Constitution of the Republic of Cameroon. Les editions de l'impremerie Nationale. YoundeP.O.Box 1603.

[26] Republic of Cameroon.(2005). Draft Document on the Sector wide to Education in Cameroon.

[27] Republic of Cameroon. Decree No 2001/041 of 19/02/2001 bearing on the organization of government School and the Appointment of school Administrators (a translation).

[28] Republic of Cameroon. Decree No 2010/0247/PM of 26 February 2010 on Decentralization.

[29] Republic of Cameroon: Law $\mathrm{N}^{0}$ 098/04/of $14^{\text {th }}$ April 1998. To lay dawn guideline for education in Cameroon.

[30] Sheriff, M. (1966). In common predicament: Social psychology of intergroup conflict and cooperation. Boston: Houghton Muffin.

[31] Tajfer, H, and Turner, J.C. (1979).An integrative theory of intergroup conflict. In W.G. Austin, and Worchel (Eds).The social psychology of intergroup relations (pp. 33-44). Monterey, C.A: Broohs/cole. 
[32] Tambo, L. I. (2003).Cameroon National Education Policy since 1995 Forum. Limbe: Design House.

[33] Tamukong, J.A. (2004) Towards Better Management of Public education in Cameroon: the Case of Decentralization. African Development. Vol. XXIX, No. 2 2004. Pp 134-157.

\section{AUTHOR'S BIOGRAPHY}

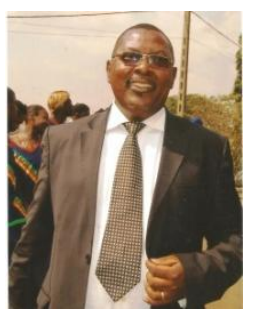

Mr. Fonge Julius Fongouck is a Ph.D. Research Fellow in the University of Buea and a school administrator (Principal of the Cameroon College of Arts and Science, Kumba). He holds a Bachelor of Arts (B.A. Hons), a Maitrise, and D.E.A. in History from the University of Yaounde, a Professional Certificate (DIPES II) also in History from Ecole Normale Superieur, Yaounde, and a Master of Education (M.Ed.) Degree in Educational Administration from the University of Buea, Cameroon. Mr. Fonge Julius Fongouck is a budding researcher, with interest in history (local and international), educational administration and resource management. Differential perception of governance roles and conflict in the management of resources: The case of stakeholders' in public secondary schools in the South West Region of Cameroon is his first article in the field of educational resource planning and management.

Citation: Fonge Julius Fongouck. "Differential Perception of Roles and Conflict in the Management of Financial Resources: The Case of Stakeholders in Public Secondary Grammar Schools in the South West Region of Cameroon" International Journal of Humanities Social Sciences and Education (IJHSSE), vol 5, no. 2, 2018, pp. 43-57. doi: http://dx.doi.org/10.20431/2349-0381.0502006.

Copyright: $\odot 2018$ Authors. This is an open-access article distributed under the terms of the Creative Commons Attribution License, which permits unrestricted use, distribution, and reproduction in any medium, provided the original author and source are credited. 